\title{
Dietary pattern, nutrient intake and growth of adolescent school girls in urban Bangladesh
}

\author{
Faruk Ahmed', Momtaz Zareen', Moududur Rahman Khan ', Cadi Pervin Banu', \\ Mohammed Nazmul Haq and Alan A Jackson ${ }^{3, *}$ \\ ${ }^{1}$ Institute of Nutrition and Food Sciences, and ${ }^{2}$ Institute of Education and Research, \\ University of Dhaka, Dhaka-1000, Bangladesh: ${ }^{3}$ Institute of Human Nutrition, \\ University of Southampton, UK
}

Submittod 10 November 1997: Accepled 11 Morch 1998

\begin{abstract}
Objective: To investigate the dietary pattern and nutritional status of adolescent girls attending schools in Dhaka city and to examine the association with various social factors.

Design: Cross-sectional study.

Setting: Girls high schools in Dhaka city.

Subjects: A total of 384 girls, aged from 10 to 16 years, who were students of classes VI to IX of 12 girls high schools in Dhaka city were selected by systematic random sampling. Nutrient intake was assessed using the $24-\mathrm{h}$ recall method and the usual pattern of food intake was examined using a 7-day food frequency questionnaire.

Results: The prevalence of undernutrition among the participants assessed as stunting was $10 \%$ overall with younger girls being less stunted (2\%) than older girls $(16 \%)$, whereas $16 \%$ were thin with relatively more of the younger girls (21\%) being thin than of the older girls (12\%). Based on the usual pattern of food intake, a substantial proportion of the girls did not consume eggs (26\%), milk (35\%) or dark green leafy vegetables $(20 \%)$. By comparison, larger proportions consumed meat $(50 \%)$ and fish (65\%) at least four times a week. For the intake of energy and protein, only 9 and $17 \%$ of the girls, respectively, met the recommended daily allowance (RDA). For nearly $77 \%$ of the girls, the intake of fat was less than the recommendation. Intakes less than the RDA were found for iron (77\% of the girls), calcium (79\%), vitamin A (62\%), vitamin C (67\%), and riboflavin (96\%). Based on the food consumption data, cereals were the major source of energy (57\%), thiamin (67\%), niacin (63\%) and iron (37\%). Animal sources supplied $50 \%$ of dietary protein. Cooking fats were the principal source of fat (67\%) in the diet. Milk was the major contributor for riboflavin and preformed vitamin A (retinol). Leafy vegetables and fruits were the main sources of provitamin A (carotenes). The girls from families with less educated parents were more likely to be thin and short for their age. Those girls from families with lower incomes and less educated parents had a dietary pattern which tended to be poor with regard to egg, milk, meat and fruit, with lower intakes of protein, fat and riboflavin.

Conclusion: The findings indicate that the diets of these girls tended to be inadequate both for macronutrients and micronutrients, with significant health implications. There was also a relationship between the family income and the education of the parents with the nutritional status of the girls.
\end{abstract}

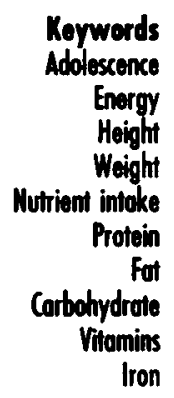

We are interested in the factors which promote good fetal growth. It is clear that the nutrition of the mother before and around the time of conception is of great importance ${ }^{1}$, hence we are especially interested in the nutritional status of mothers before they become pregnant. In situations when the first pregnancy is likely to occur during the teenage years, the physical growth, mental and sexual development of girls during adolescence may have a critical effect on their capacity to carry successful pregnancies and the health and nutritional status of today's adolescent girls will largely determine the quality of the next generation. During adolescence $15-25 \%$ of the adult height is achieved and $45 \%$ of the skeletal development occurs ${ }^{2}$. In undernourished populations the tempo of growth during adolescence is slower ${ }^{3}$ and using either the maximal height spurt or menarche as an indicator of maturation, may be delayed by 
24 months on average in undernourished girls ${ }^{4}$. Complications of pregnancy and complications of labour are directly related to nutrition with poor bony growth resulting in contracted pelvis and difficult labour, and greater risks of increased maternal and infant mortality.

Meeting the increased demands for energy and nutrients is critical around the time of puberty if sexual development and the adolescent growth spurt are to be sustained. It has been suggested that protein might be specially important ${ }^{5}$, but there are also increased demands for other nutrients. Iron has been shown to be limiting for growth during adolescence when the intake is deficient ${ }^{6}$ and it may be that for adolescent girls in developing countries, the requirement for iron is even higher because of the effect of infections such as malaria, schistosomiasis and hookworm, and the effects of inflammation on iron absorption ${ }^{7}$. Vitamin $\mathrm{A}$ has also been implicated as being important for growth, development and sexual maturation, with a positive association being reported between plasma retinol and indices of sexual maturation ${ }^{8}$. Brabin and Brabin $^{7}$ noted a rise in the concentration of retinol-binding protein in serum with puberty. Skeletal development increases the need for calcium, which appears to be greater during adolescence than either childhood or young adulthood ${ }^{9}$.

In Bangladesh, nutritional problems, a consequence of poor dietary intake, are widespread and persistent. A national nutritional survey was carried out in the rural parts of Bangladesh in $1981-82^{10}$ and showed that for adolescent girls, the per capita energy intake was only $81 \%$ of the recommended dietary allowance (RDA) on average ${ }^{11}$ and for vitamin A only $20-58 \%$ of the RDA, depending on the age ${ }^{10}$. Bangladesh is a society in transition and development brings changes in life-style which include changes in food habits, often most obvious in adolescents in urban centres. Despite these major considerations, adolescent nutrition has not received a great deal of attention. There have been no systematic studies to characterize the dietary intake of adolescent girls in Bangladesh. The national survey only covered the rural population and although it included adolescents they were not identified as a distinct population group. Recently we studied a selected group of adolescent girls from four schools in upper middle class residential areas of Dhaka city and found that $22 \%$ had a haemoglobin below $120 \mathrm{gl}^{-1}$ and in $11 \%^{12}$ the serum vitamin A was less than $1.05 \mu \mathrm{moll}^{-1}$. The present study was carried out to assess the dietary intake and nutritional status of a representative sample of adolescent girls from high schools in Dhaka city, and factors which might influence nutritional status were explored.

\section{Methods}

\section{Subjects and materials}

\section{Subject identification and selection}

The students of classes VI-IX of 12 girls high schools in Dhaka city participated in the study. There were 384 girls, aged from 10 to 16 years. The study was approved by the Institute of Nutrition and Food Sciences (INFS), University of Dhaka, and was conducted during MayAugust 1995. Participants were selected using a multistage sampling technique which included all 12 thanas (administrative units) in the Dhaka metropolitan area. One school from each thana was selected by simple random sampling and for each school, 32 students, eight from each class, were selected by systematic random sampling.

The purpose of the study was explained to the authority of each school selected and their permission was sought to carry out the work on their students. The administrations of all schools consented readily. Each student selected was handed a letter addressed to her parents, which sought written permission to include their ward in the study.

\section{Questionnaire and sample collection}

A questionnaire which requested information on socioeconomic status, personal characteristics and dietary intake was designed and pretested before finalization. Parents were asked about the date of birth of their ward, family size, monthly family income and expenditure on food, their academic qualifications and occupation. The dietary intake data were furnished by the participants themselves.

\section{Data collection}

The schools were visited for data collection on prefixed dates. The school administration and the students were informed of the dates well in advance of the visit.

\section{Antbropometric measurement}

The weight and height of each participant was taken, using standard methods which have been validated ${ }^{12}$. For each subject stunting was assessed on the basis of height for age (ht/age) being below the 3 rd percentile, using a 12-month age bracket ${ }^{13}$, with the US National Center for Health Statistics as the reference ${ }^{14}$. The degree of wasting, or thinness, was determined as a body mass index (BMI) for age below the 5 th percentile for age ${ }^{13}$.

\section{Dietary information}

Food consumption was assessed with the 24-h dietary recall method using school days only and thus diet at the weekend was not recorded. In order to increase the reliability of the estimates of portion sizes for individual 
foods consumed, we used styrofoam models for different foods, and displayed serving plates, cups and spoons of different sizes. From this the weight of each serving of the different food items was calculated. The equivalent weight of the raw food was calculated using a conversion table for Bangladeshi foods formulated at the INFS ${ }^{15}$. A programme package, based on Bangladeshi and Indian food composition tables developed at the INFS was used to calculate nutrient intake from raw food weight ${ }^{16,17}$. A 7-day food frequency questionnaire on selected food items was used to obtain information on the habitual dietary pattern of each participant.

\section{Statistical analysis}

Data were analysed using the SPSS/PC (version 4.1) statistical package ${ }^{18}$ with univariate analysis for simple frequency distribution of selected variables. For each of the variables, normality of the distribution of the data was assessed, with the Kolmogorov-Smirnov goodness of fit test. The mean, median, standard deviation and range were determined for all parameters. The data were divided into two groups using suitable cut-off points. For per capita income by household the cut-off, Tk. 583 per month (US $\$ 1=$ Tk. (Taka) 42.4) was defined as the level set for household poverty line expenditure, based on the normative per capita daily minimum energy intake $(2112 \mathrm{kcal})$ at the 1995 prices of food items with an allowance of $25 \%$ for non-food basic needs. Accordingly, the cut-off point for per capita expenditure on food, Tk. 466, was identified as $25 \%$ less than the household poverty line expenditure $^{19}$. For the educational level of the parents, the cutoff point was between class IX and X. One-way analysis of variance was carried out to determine the relationship between these factors and either the dietary intake or the nutritional status of the girls.

\section{Results}

The girls came from families in which the parents had achieved a high educational level. Very few of the fathers $(2.1 \%)$ or the mothers $(4.7 \%)$ were illiterate. Of the fathers $16 \%$ had some formal education (grade IIX), $34 \%$ a secondary or higher secondary certificate and $48 \%$ were graduates. For mothers the figures were 36,42 and $18 \%$, respectively. Most of the families (59\%) were of medium size, five to seven members, with $11 \%$ of families having up to four members and $30 \%$ over seven members. A family income less than Tk. 5000 per month was considered to be low and was found in $30 \%$ of households. A high income (over Tk. 10,000) was found in $35 \%$ of households and a medium income (Tk. $5001-10,000$ ) was found in $35 \%$ of households. There was wide variation in the amount spent on food with $32 \%$ of households spending less than Tk. 3000 per month, $46 \%$ from Tk. 3001 to 6000 per month and $22 \%$ spending over Tk. 6000 per month.

Of the participants, $43 \%$ were aged between 10 and 12 years and the remaining $57 \%$ were between 13 and 16 years old. When the mean height and weight of the participants were compared as a group with the reference NCHS median they were found to be normal. Figure 1 shows the pattern of stunting and thinness for each age category. The prevalence of stunting increased from 10 to 15 years of age, with $10 \%$ of girls being stunted on average. For the group as a whole, $16 \%$ of the girls were thin and thinness was more common in the younger girls than in those older. Of the girls, $10 \%$ were found to be overweight (wt/ht $>120 \%$ ).
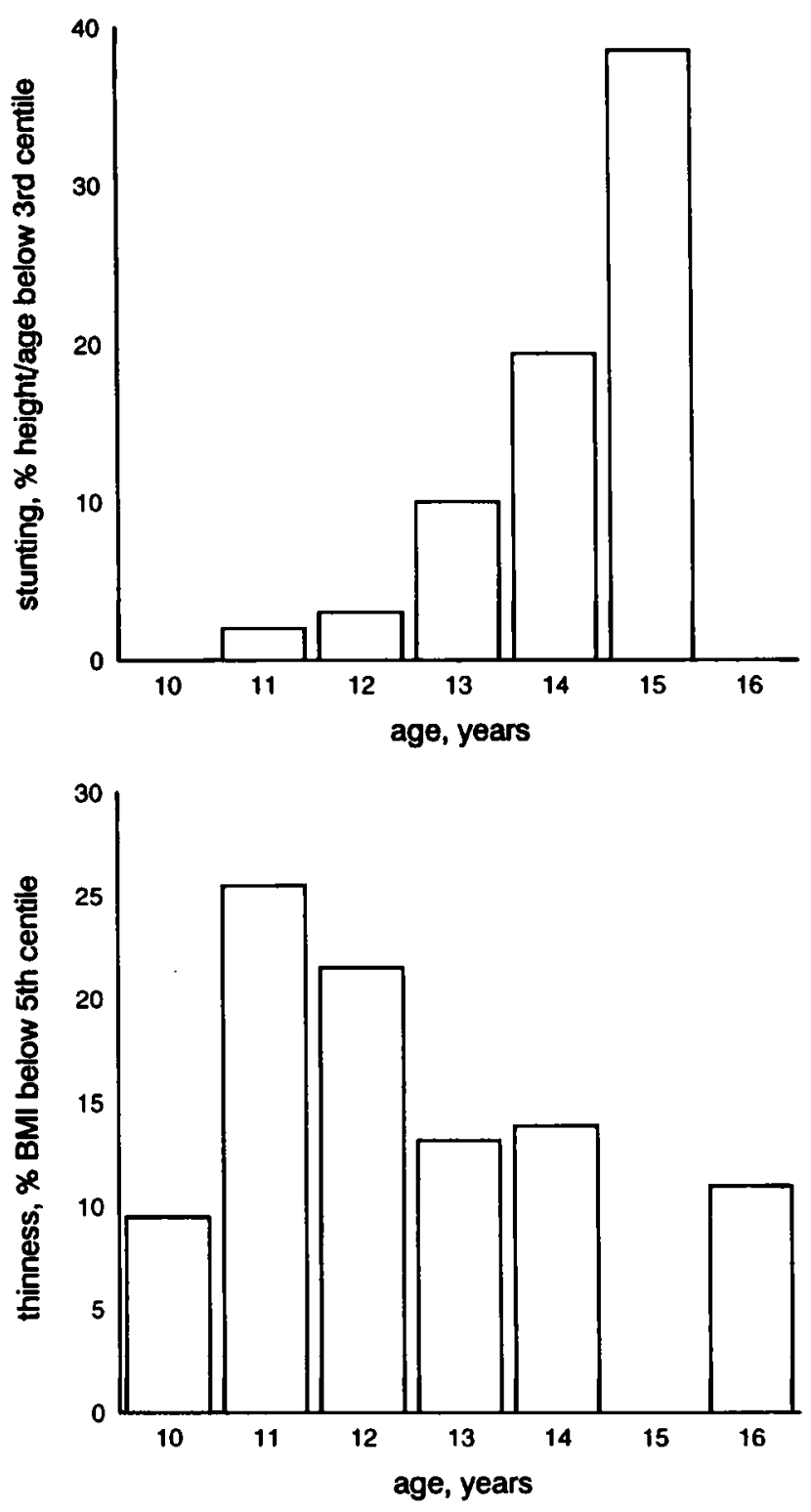

Fig. 1 The height and weight was taken of 384 schoolgirls in Dhaka city, Bangladesh, and the degree of stunting and thinness determined for each year age group from 10 to 16 years of age. 
Table 1 The weekly pattern of consumption of food items by 384 girls at schools in Dhaka city, who participated in a study of dietary pattems, expressed as the percentage of girls consuming with different frequencies

\begin{tabular}{lcccc}
\hline & \multicolumn{4}{c}{ Frequency of consumption, times per week } \\
\cline { 2 - 5 } & $0(\%)$ & $1-3(\%)$ & $4-6(\%)$ & 7 or more (\%) \\
\hline Eggs & 26 & 46 & 15 & 13 \\
Milk & 35 & 24 & 12 & 29 \\
Meat & 10 & 40 & 30 & 20 \\
Fish & 12 & 23 & 25 & 40 \\
Dark green leafy vegetables & 20 & 47 & 23 & 10 \\
Fruits & 1 & 7 & 13 & 79 \\
\hline
\end{tabular}

For selected food items the distribution according to the frequency of consumption is shown in Table 1 . The mean frequency of consumption each week was for eggs 2.6, milk 3.3, meat 4.3, fish 6.0, dark green leafy vegetables 3.0 and fruits 14.2 . It can be seen that for a substantial proportion of the girls eggs (26\%) and milk (35\%) were not consumed at all, whereas over $50 \%$ of the girls consumed meat and fish at least four times a week. While nearly $80 \%$ of girls consumed fruits seven or more times in the week, $20 \%$ did not take dark green leafy vegetables at all. Cereals were the major source of energy (57\%) and about $36 \%$ of the total protein intake came from cereals. Other sources of protein were milk $(8.2 \%)$, eggs (16\%), meat (22\%) and pulses (10\%). Visible fat represented the principal source of dietary fat (67\%). Milk (33\%) and eggs (37\%) were the major contributors for calcium. For iron, cereals were the major source $(37 \%)$. The mean intake of preformed vitamin A (retinol) was $435 \mu$ day $^{-1}$ with milk being the major contributor $(61 \%)$. The mean intake of carotene (provitamin A) was $3148 \mu \mathrm{g} \mathrm{day}^{-1}(525 \mu \mathrm{g}$ retinol equivalent). Dark green leafy vegetables provided nearly $50 \%$ of total carotene in the diet with other vegetables (15\%) and fruits (31\%) making important contributions. Nearly two-thirds of total thiamin and niacin intake came from cereals. Milk provided $50 \%$ of the riboflavin intake.

The average daily intakes by the participants for energy and nutrients are shown in Table 2 , by age group, and for the distribution in relation to the RDA for

Table 2 The energy and nutrient intakes of 384 girls at schools in Dhaka city, who participated in a study of dietary patterns, by age group, and the percentage who fell into different categories based upon the extent to which the dietary intake satisfied the RDA*

\begin{tabular}{|c|c|c|c|c|c|c|c|c|c|c|}
\hline & & & \multicolumn{4}{|c|}{ Age group } & & & & \\
\hline & \multicolumn{2}{|c|}{ Total } & \multicolumn{2}{|c|}{$10-12$ years } & \multicolumn{2}{|c|}{ 13-16 year } & \multicolumn{4}{|c|}{ Percentage of RDA } \\
\hline & Mean & SD & Mean & SD & Mean & SD & $<50 \%$ & $50-74 \%$ & $75-99 \%$ & $\geqslant 100$ \\
\hline $\begin{array}{l}\text { Energy (kcal day }{ }^{-1} \text { ) } \\
\mathrm{kcal} \mathrm{kg} \text { body weight day }{ }^{-1}\end{array}$ & $\begin{array}{r}1465 \\
38\end{array}$ & $\begin{array}{r}431 \\
13\end{array}$ & $\begin{array}{r}1460 \\
42\end{array}$ & $\begin{array}{r}398 \\
14\end{array}$ & $\begin{array}{r}1468 \\
35\end{array}$ & $\begin{array}{r}456 \\
12\end{array}$ & 10 & 56 & 25 & 9 \\
\hline $\begin{array}{l}\text { Carbohydrate }\left(\mathrm{g} \mathrm{day}^{-1}\right) \\
\% \text { energy }\end{array}$ & $\begin{array}{r}231 \\
63\end{array}$ & $\begin{array}{l}75 \\
8.7\end{array}$ & $\begin{array}{r}228 \\
63\end{array}$ & $\begin{array}{l}64 \\
8.4\end{array}$ & $\begin{array}{r}234 \\
64\end{array}$ & $\begin{array}{l}83 \\
8.8\end{array}$ & & & & \\
\hline $\begin{array}{c}\text { Fat }\left(\text { g day }^{-1}\right) \\
\% \text { energy }\end{array}$ & $\begin{array}{l}39 \\
24\end{array}$ & $\stackrel{17}{7.3}$ & $\begin{array}{l}40 \\
24\end{array}$ & $\begin{array}{l}18 \\
7.2\end{array}$ & $\begin{array}{l}39 \\
24\end{array}$ & $\begin{array}{l}17 \\
7.4\end{array}$ & 12 & 33 & 32 & 23 \\
\hline $\begin{array}{l}\text { Protein }\left(g \text { day }^{-1} \text { ) }\right. \\
\% \text { energy }\end{array}$ & $\begin{array}{l}48 \\
13\end{array}$ & $\begin{array}{c}18 \\
2.8\end{array}$ & $\begin{array}{l}48 \\
13\end{array}$ & $\begin{array}{l}18 \\
2.9\end{array}$ & $\begin{array}{l}47 \\
13\end{array}$ & $\begin{array}{l}18 \\
2.8\end{array}$ & 17 & 46 & 20 & 17 \\
\hline Calcium (mg day ${ }^{-1}$ ) & 399 & 294 & 423 & 333 & 381 & 261 & 48 & 17 & 14 & 21 \\
\hline Iron (mg day ${ }^{-1}$ ) & 10 & 7.0 & 9.0 & 7.1 & 9.5 & 6.7 & 31 & 35 & 11 & 23 \\
\hline Vitamin A (retinol equivalents day ${ }^{-1}$ ) & 960 & 1492 & 935 & 1519 & 982 & 1477 & 44 & 10 & 8 & 38 \\
\hline Thiamin (mg day ${ }^{-1}$ ) & 0.8 & 0.3 & 0.8 & 0.3 & 0.8 & 0.3 & $\mathbf{8}$ & 40 & 34 & 18 \\
\hline Riboflavin (mg day ${ }^{-1}$ ) & 0.5 & 0.3 & 0.6 & 0.3 & 0.5 & 0.3 & 67 & 21 & 8 & 4 \\
\hline Niacin (mg day ${ }^{-1}$ ) & 14 & 5.3 & 14 & 4.9 & 14 & 5.6 & 3 & 23 & 34 & 40 \\
\hline Ascorbate $\left(\mathrm{mg} \mathrm{day}^{-1}\right)$ & 43 & 55 & 44 & 55 & 42 & 55 & 37 & 18 & 12 & 33 \\
\hline
\end{tabular}

"Based on the safe level (mean \pm 2 SD) according to ICMR ${ }^{31}$ except for fat and iron. For fat based on upper limit of safe ranges for mean requirement ${ }^{32}$ and for iron based on median basal requirement on intermediary bioavailability diet ${ }^{33}$. RDA for energy, protein and niacin was adjusted for age group. 
energy and nutrients. On average there were no obvious differences in the intakes of energy or various nutrients by age group. The mean intakes of energy and protein were below the RDA at all ages. The intake of energy and protein were skewed to the lower values and of the participants, $91 \%$ had energy intakes below the RDA (1970 kcal day ${ }^{-1}$ for girls aged 10-12 years; $2060 \mathrm{kcal} \mathrm{day}^{-1}$ for girls aged 13-16 years). About $83 \%$ had protein intakes below the RDA $\left(57 \mathrm{~g} \mathrm{day}^{-1}\right.$ for girls aged 10-12 years; $65 \mathrm{~g} \mathrm{day}^{-1}$ for girls aged 13-16 years). For total fat intake, $77 \%$ of the girls had intakes which were less than $30 \%$ of total food energy, the recommended fat intake. Of the micronutrients, mean intakes of calcium, iron, thiamin and riboflavin were below the RDA; while vitamin A, niacin and vitamin $C$ met the RDA. The intakes of calcium, iron, vitamin A, thiamin, riboflavin, niacin and ascorbate were skewed to the lower values and of the participants, $79 \%$ had calcium (RDA $600 \mathrm{mg} \mathrm{day}^{-1}$ ), $77 \%$ had iron (RDA for 10-12 years: $9.5 \mathrm{mg} \mathrm{day}^{-1}$; $11-14$ years: $16.0 \mathrm{mg} \mathrm{day}^{-1}$; and $15-16$ years: $12.5 \mathrm{mg} \mathrm{day}^{-1}$ ), $62 \%$ had vitamin $A$ (RDA $600 \mu \mathrm{g} \mathrm{day}^{-1}$ ), 82\% had thiamin (RDA $1.0 \mathrm{mg}$ day $^{-1}$ ), $96 \%$ had riboflavin (RDA $1.2 \mathrm{mg} \mathrm{day}^{-1}$ ), $60 \%$ had niacin (RDA for 10-12 years: $13 \mathrm{mg} \mathrm{day}^{-1}$; and 1316 years: $14 \mathrm{mg} \mathrm{day}^{-1}$ ) and $67 \%$ had vitamin $\mathrm{C}$ (RDA $40 \mathrm{mg} \mathrm{day}^{-1}$ ) intakes less than RDA.

The relationship between the anthropometric indices of nutritional status of the girls and various socioeconomic factors are shown in Table 3. The girls were divided into two group based upon the household per capita income, expenditure on food, fathers' educational level and mothers' educational level. There was no difference in weight for age, height for age, weight for height or BMI amongst girls from higher income families ( $\geq$ Tk. 583 per month) and the girls from lower income families ( $<$ Tk. 583 per month), nor for girls from families where the per capita expenditure on food was higher ( $\geq T k$. 466 per month) compared with the girls from families with lower expenditure ( $<$ Tk. 466 per month). For fathers who had higher levels of educational attainment (grade $\mathrm{X}$ and above), the daughters had greater wt/age, ht/age and BMI, when compared with the daughters of fathers who had less formal education (up to grade IX), however, the difference was only statistically significant for wt/age. The girls of less educated (up to grade IX) mothers were significantly more underweight and shorter compared with the girls of higher educated mothers (grade $\mathrm{X}$ and above).

Using the same bivariate groupings, the relationships with dietary patterns were examined (Table 4). The girls from families where income was higher or where more was spent on food were more frequent consumers of eggs, milk and meat. There was more frequent consumption of eggs and meat by the girls whose fathers were more highly educated. The frequency of consumption of eggs, milk, meat and fruits was greater in girls whose mothers had higher levels of education.

The relationship amongst the intake of nutrients and various socioeconomic factors are presented in Table 5. Girls from lower income families had intakes of protein, fat and riboflavin which were significantly lower than the girls from higher income families and the findings were similar in relation to expenditure on food. Similarly, girls who had parents with lower levels of education had lower intakes of protein, fat and riboflavin than girls with more highly educated parents.

\section{Discussion}

Problems related to food intake and malnutrition have been identified as widespread and important concerns for public health in Bangladesh. Over recent decades many studies have been carried out to identify the extent and consequence of malnutrition in different population groups, and they have tended to place emphasis on those identified as most vulnerable;

Table 3 Relationship between socioeconomic conditions and anthropometric indices of adolescent girls in Dhaka city

\begin{tabular}{|c|c|c|c|c|c|}
\hline & $n$ & $\begin{array}{c}\text { Wt/age } \\
\text { mean }(95 \% \mathrm{CI})\end{array}$ & $\begin{array}{c}\mathrm{H} \text { t/age } \\
\text { mean }(95 \% \mathrm{Cl})\end{array}$ & $\begin{array}{c}\text { Wt/ht } \\
\text { mean }(95 \% \mathrm{Cl})\end{array}$ & $\begin{array}{c}\text { BMI } \\
\text { mean }(95 \% \mathrm{CI})\end{array}$ \\
\hline \multicolumn{6}{|l|}{ Per capita income } \\
\hline $\begin{array}{l}\text { Low (<Tk.583) } \\
\text { High ( } \geqslant \text { Tk. 583) }\end{array}$ & $\begin{array}{r}\mathbf{6 1} \\
\mathbf{3 1 5}\end{array}$ & $\begin{array}{c}90.9(86.0-95.9) \\
92.5(90.5-94.5) \\
P=0.55\end{array}$ & $\begin{array}{c}97.7(96.5-99.0) \\
98.0(97.5-98.6) \\
P=0.62\end{array}$ & $\begin{array}{c}97.2(94.8-99.6) \\
100.0(98.0-102.1) \\
P=0.087\end{array}$ & $\begin{array}{c}17.6(16.9-18.4) \\
17.8(17.4-18.1) \\
P=0.76\end{array}$ \\
\hline $\begin{array}{l}\text { Per capita expenditure } \\
\text { Low (<Tk. 466) } \\
\text { High ( } \geqslant \text { Tk. 466) }\end{array}$ & $\begin{array}{r}93 \\
282\end{array}$ & $\begin{array}{c}91.3(86.7-91.5) \\
92.5(90.6-94.5) \\
P=0.56\end{array}$ & $\begin{array}{c}97.5(96.5-98.5) \\
98.2(97.7-98.8) \\
P=0.18\end{array}$ & $\begin{array}{c}99.0(95.9-102.1) \\
98.9(97.0-100.7) \\
P=0.93\end{array}$ & $\begin{array}{c}17.6(17.0-18.2) \\
17.8(17.4-18.1) \\
P=0.74\end{array}$ \\
\hline $\begin{array}{l}\text { Father's education } \\
\text { Up to class IX } \\
\text { Class } X \text { and above } \\
\text { Mother's education }\end{array}$ & $\begin{array}{r}67 \\
310\end{array}$ & $\begin{array}{c}87.7(83.8-91.5) \\
93.2(91.1-95.3) \\
P=0.023\end{array}$ & $\begin{array}{c}97.1(96.1-98.0) \\
98.2(97.7-98.8) \\
P=0.06\end{array}$ & $\begin{array}{c}96.8(93.5-100.1) \\
99.9(97.6-101.2) \\
P=0.22\end{array}$ & $\begin{array}{c}17.2(16.7-17.8) \\
17.8(17.5-18.2) \\
P=0.12\end{array}$ \\
\hline $\begin{array}{l}\text { Up to class IX } \\
\text { Class } X \text { and above }\end{array}$ & $\begin{array}{l}154 \\
222\end{array}$ & $\begin{array}{c}88.7(86.0-91.5) \\
94.4(92.0-96.9) \\
P=0.003\end{array}$ & $\begin{array}{c}97.0(96.3-97.8) \\
98.6(98.0-99.2) \\
P=0.001\end{array}$ & $\begin{array}{c}98.5(96.1-100.9) \\
99.3(97.2-101.4) \\
P=0.62\end{array}$ & $\begin{array}{c}17.5(17.1-18.0) \\
17.9(17.5-18.3) \\
P=0.26\end{array}$ \\
\hline
\end{tabular}




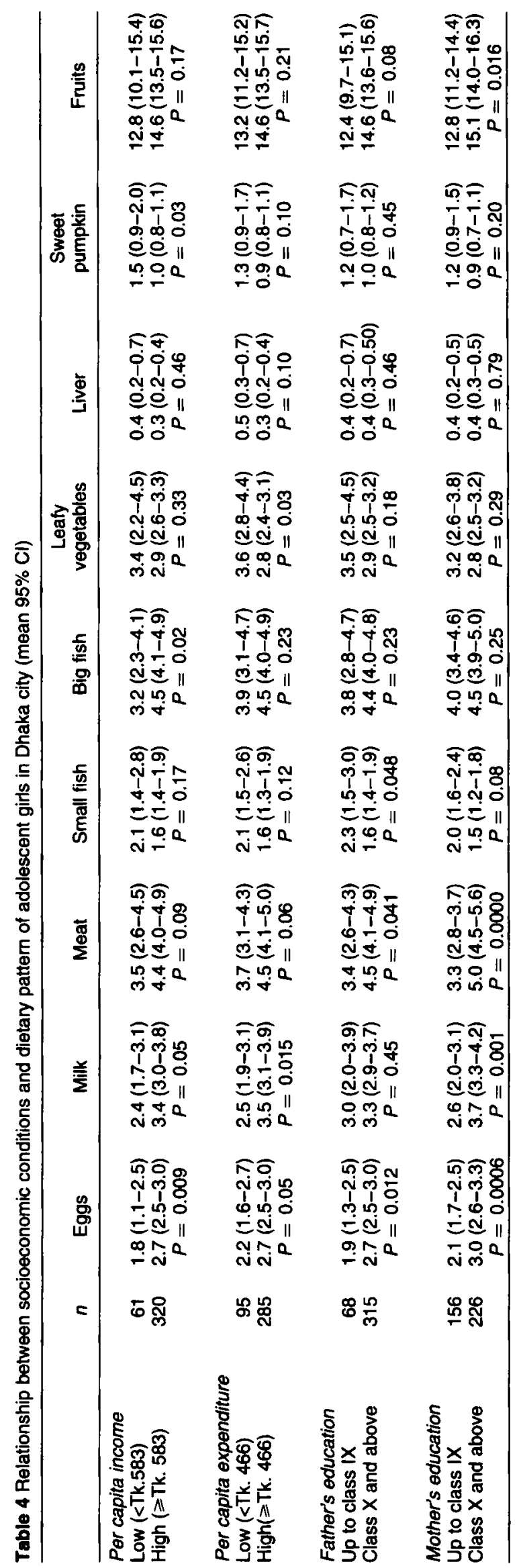


Table 5. Relationship between family income, expenditure on food and education level of father and mother on nutrient intake amongst adolescent girls in Dhaka city

\begin{tabular}{|c|c|c|c|c|c|c|}
\hline & \multicolumn{2}{|c|}{$\begin{array}{l}\text { Per capita income } \\
\text { (mean } \pm 95 \% \mathrm{Cl} \text { ) }\end{array}$} & \multirow[b]{2}{*}{$P$ value } & \multicolumn{2}{|c|}{$\begin{array}{l}\text { Per capita food expenditure } \\
\text { (mean } \pm 95 \% \text { Cl) }\end{array}$} & \multirow[b]{2}{*}{$P$ value } \\
\hline & $\begin{array}{l}\text { <Tk. } 583 \\
(n=61)\end{array}$ & $\begin{array}{l}\geqslant \text { TK. } 583 \\
(n=320)\end{array}$ & & $\begin{array}{l}<T k .466 \\
(n=95)\end{array}$ & $\begin{array}{l}\geqslant \text { Tk. } 466 \\
(n=285)\end{array}$ & \\
\hline \multirow[t]{3}{*}{ 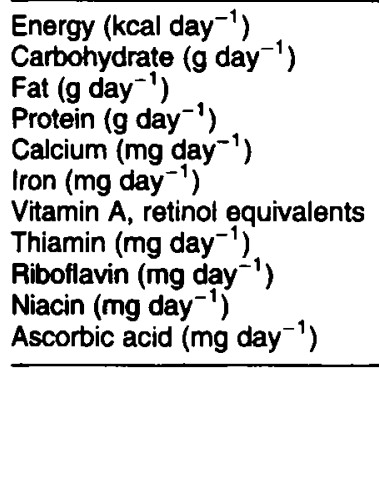 } & $\begin{array}{c}1399(1282-1516) \\
233(211-255) \\
33.2(29.3-37.2) \\
42.2(38.0-46.4) \\
345(273-416) \\
9.4(7.7-11.1) \\
921(578-1264) \\
0.75(0.68-0.82) \\
0.44(0.38-0.49) \\
12.7(11.4-14.0) \\
30.6(19.9-41.4)\end{array}$ & $\begin{array}{c}1477(1430-1523) \\
231(223-239) \\
40.2(38.2-42.1) \\
48.7(46.6-50.7) \\
410(377-442) \\
9.8(9.0-10.6) \\
974(806-1142) \\
0.80(0.77-0.83) \\
0.55(0.51-0.58) \\
14.1(13.5-14.7) \\
45.4(39.2-51.7)\end{array}$ & $\begin{array}{l}0.20 \\
0.87 \\
0.004 \\
0.01 \\
0.12 \\
0.69 \\
0.80 \\
0.15 \\
0.01 \\
0.055 \\
0.055\end{array}$ & $\begin{array}{c}1443(1346-1541) \\
237(218-255) \\
35.6(32.5-38.8) \\
45.0(41.4-48.6) \\
388(326-450) \\
9.4(8.2-10.6) \\
952(667-1237) \\
0.78(0.72-0.84) \\
0.46(0.41-0.51) \\
13.5(12.4-14.7) \\
45.3(34.0-56.7)\end{array}$ & $\begin{array}{c}1469(1420-1517) \\
229(221-237) \\
40.1(38.1-42.2) \\
48.5(46.4-50.7) \\
403(369-437) \\
9.7(8.9-10.5) \\
961(783-1139) \\
0.80(0.76-0.83) \\
0.55(0.51-0.59) \\
14.0(13.4-14.6) \\
41.9(35.6-48.3)\end{array}$ & $\begin{array}{l}0.62 \\
0.42 \\
0.03 \\
0.11 \\
0.67 \\
0.66 \\
0.96 \\
0.69 \\
0.02 \\
0.48 \\
0.60\end{array}$ \\
\hline & \multicolumn{2}{|c|}{ Father's education } & & \multicolumn{2}{|c|}{ Mother's education } & \\
\hline & $\begin{array}{l}\text { Up to class IX } \\
\quad(n=68)\end{array}$ & $\begin{array}{c}\text { Class } X \text { and above } \\
\quad(n=315)\end{array}$ & & $\begin{array}{l}\text { Up to class } I X \\
(n=156)\end{array}$ & $\begin{array}{c}\text { Class } X \text { and above } \\
(n=226)\end{array}$ & \\
\hline 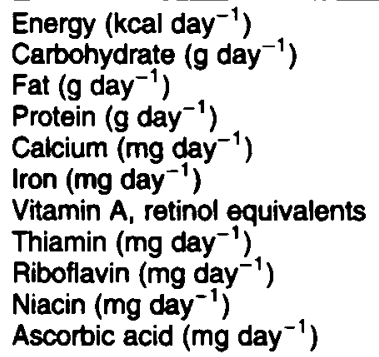 & $\begin{array}{c}1389(1286-1492) \\
227(209-246) \\
34.3(30.6-38.0) \\
42.9(39.1-46.7) \\
404(327-480) \\
9.3(7.6-11.0) \\
836(506-1165) \\
0.73(0.68-0.80) \\
0.46(0.38-0.53) \\
12.5(11.4-13.6) \\
37.8(23.9-51.8)\end{array}$ & $\begin{array}{c}1480(1432-1528) \\
232(224-240) \\
40.2(38.3-42.1) \\
48.6(46.6-50.7) \\
398(366-430) \\
9.8(9.0-10.5) \\
983(814-1152) \\
0.80(0.77-0.84) \\
0.55(0.51-0.58) \\
14.1(13.5-14.8) \\
43.6(37.7-49.6)\end{array}$ & $\begin{array}{l}0.11 \\
0.65 \\
0.01 \\
0.02 \\
0.88 \\
0.63 \\
0.46 \\
0.07 \\
0.04 \\
0.02 \\
0.43\end{array}$ & $\begin{array}{c}1429(1359-1499) \\
233(221-246) \\
35.7(33.2-38.2) \\
44.0(41.3-46.7) \\
371(324-417) \\
9.4(8.3-10.5) \\
829(625-1033) \\
0.76(0.72-0.80) \\
0.46(0.41-0.50) \\
13.3(12.5-14.1) \\
44.7(34.9-54.5)\end{array}$ & $\begin{array}{c}1489(1434-1544) \\
230(221-240) \\
41.4(39.1-43.7) \\
50.0(47.6-52.5) \\
419(380-458) \\
10.0(9.0-10.9) \\
1054(842-1266) \\
0.81(0.78-0.85) \\
0.58(0.54-0.62) \\
14.3(13.6-15.0) \\
41.7(35.2-48.2)\end{array}$ & $\begin{array}{l}0.18 \\
0.69 \\
0.001 \\
0.001 \\
0.11 \\
0.44 \\
0.15 \\
0.10 \\
0.0001 \\
0.07 \\
0.60\end{array}$ \\
\hline
\end{tabular}

infants, preschool children, pregnant and lactating mothers. The present study has sought to focus on the nutritional status and dietary patterns of adolescent school girls in the urban areas of Bangladesh for two reasons. Firstly, these represent the most advantaged group in the country, their health marks the best achieved at the present time and they will act as role models for others in the society. Secondly, they will shortly become mothers and their growth during adolescence will in part mark their ability to carry a successful pregnancy, and thereby determine the wellbeing of the next generation. Any interventions designed to have a long-term impact on the health of the country have to include a focus on adolescent girls. Adolescence, as a period of rapid growth, requires a sufficient intake of energy and other nutrients for timely sexual maturation and to achieve the full potential for growth and physical work capacity ${ }^{20,21}$. It is also a period during which change in behaviour and attitude, which can lead to improper dietary habits, may be set for life ${ }^{22}$. Adolescent school children in Glasgow were found to have low energy intakes ${ }^{23}$ and more specifically, girls under 18 years of age may be particularly likely to have inadequate intakes of energy $^{24}$. In the Canadian National Nutrition Survey ${ }^{25}$ it was found that the diets of teenagers were commonly substandard with respect to iron, calcium, vitamins A, D and $\mathrm{C}$, and riboflavin. Leibel ${ }^{26}$ reported that the diets of Western adolescents were deficient in calcium, iron and zinc. Aberrations in food habits rather than a limited availability of food has been implicated in the low intake of nutrients. The present study sought to depict the nutritional situation of urban adolescent school girls in Bangladesh. As a country entering transition, it might be expected that the patterns seen in girls coming from educated families of relatively higher social position and better economic conditions anticipate the patterns of the future.

If height is taken as the most representative figure for overall growth and development ${ }^{26}$, about 1 in 10 girls showed evidence of stunting, and this appeared to increase with age. We were not able to make any assessment of maturity, but we would expect any delay in timing to be reflected in a delay in the maximum height spurt and hence an increased prevalence of shortness in a cross-sectional study. Therefore, it may be that the increase in stunting with age is a reflection of chronic nutritional problems, severe enough to slow maturation. On average the proportion of participants with thinness was about $16 \%$, being more evident in younger (21\%) than older girls (12\%), but similar to an estimate of $13 \%$ in an earlier study in 225 adolescent girls $^{12}$. The extent to which thinness reflects intrinsic differences in body habitus compared with the 
reference population or problems directly related to nutrition needs to be determined.

The 7-day food frequency questionnaire revealed very wide differences in the pattern of foods taken by the girls, to the extent that it would be difficult to characterize a representative diet. The diets were based upon cereals, which provided $57 \%$ of the energy, with only $16 \%$ of energy being derived from fats and oils. The mean energy intake, $1465 \mathrm{kcal} \mathrm{day}^{-1}$, was $74 \%$ of the requirement, which compares with an energy intake of rural girls of $1745 \mathrm{kcal} \mathrm{day}^{-1}$ at $10-12$ years of age and $1973 \mathrm{kcal} \mathrm{day}^{-1}$ at 13-15 years, according to the most recent nutrition survey of rural Bangladesh ${ }^{10}$. Over $50 \%$ of the girls had energy intakes below $75 \%$ of the RDA (see Table 3). On this basis it can be concluded that the total food intake was less than optimal and may be related directly to the frequency of wasting.

Eggs, milk, meat and fish were the major sources of protein, calcium and preformed vitamin A. Although half the girls took meat and fish regularly, at least four times a week, the relatively large numbers who never took eggs, milk or green leafy vegetables had an important impact on the overall nutrient intake. The mean protein intake was similar to that of rural girls ${ }^{10}$, with animal protein and pulses accounting for about $60 \%$ of total protein intake, and cereals providing $36 \%$. Nearly $50 \%$ of the girls had a protein intake of less than $75 \%$ of the RDA for their age (see Table 2). The mean intake of calcium, $399 \mathrm{mg} \mathrm{day}^{-1}$, was $70 \%$ of the RDA, but nearly half of the girls had a calcium intake below $50 \%$ of the RDA (see Table 2).

The mean intake of vitamin A was $160 \%$ of the RDA, but this masks important differences within the group as a whole. Only $38 \%$ met the RDA for vitamin A and about $44 \%$ of the girls had less than $50 \%$ of the RDA (see Table 2). About $45 \%$ of the total vitamin A intake was preformed vitamin A (retinol), with milk being the major source $(61 \%)$. Liver, a rich source of preformed vitamin A, was not taken by over $80 \%$ of the respondents. Most of the retinol equivalents were taken in the form of provitamin A (carotene) from plant sources, with dark green leafy vegetables $(50 \%)$ and fruits (31\%) being the major sources. Although the frequency of fruit consumption was high, one-fifth of girls never consumed green leafy vegetables. The mean intake of vitamin $\mathrm{A}$ by the urban adolescent girls was much higher than that reported for rural girls ${ }^{10}$, and the difference is most likely due to the higher intake of preformed vitamin A in the urban situation.

As well as providing provitamin A, dark green leafy vegetables and fruits are major sources of vitamin $C$ and minerals, especially iron. The mean daily intake of iron, $10 \mathrm{mg} \mathrm{day}^{-1}$, was only $51 \%$ of the RDA and two-thirds had iron intakes below $50 \%$ of the RDA (see Table 2). Compared with the intake of rural girls the mean intake of iron was less than half ${ }^{10}$. In part this difference might be accounted for by changes in the reference food composition tables. The tables have been revised and updated after reanalysis of foods for iron content using modern techniques. In consequence, the iron content of several foods in the new edition differ from earlier editions. For example, rice is a major source of iron in the diets of our subjects, but the value for iron in rice in the current table is much lower than in the earlier edition. In the present study the most recent estimates have been used to calculate nutrient intakes ${ }^{17}$. Iron availability might be influenced by the dietary content of vitamin $\mathrm{C}$ and as fruits were taken regularly by virtually all girls, the RDA was met on average, although there were about one-third who had an intake less than $50 \%$ of the RDA. The B group of vitamins presented a clear problem for this group and the mean daily intakes of thiamin and riboflavin were below the RDA, although the mean intake of niacin met the RDA. Milk provided half and cereals two-fifths of the total riboflavin intake and two-thirds of the girls had riboflavin intakes below $50 \%$ of the RDA. Cereals were the major source of thiamin (67\%) and niacin (63\%). It was not possible to calculate the intakes of folic acid, zinc and vitamin $E$ because the food values for these nutrients are not available.

The results of the present study represent the intakes during a $24-\mathrm{h}$ period preceding the interview which only included school days. The intake on school days may differ from that on weekends and other holidays, but this is taken into account by the use of the food frequency questionnaire. It is clear that the dietary pattern of many young girls exposes them to the risk of specific nutrient problems. The fact that they are, by and large, thinner than the reference standard, together with the data on energy intakes, suggests that their energy intake is not adequate. Given that prepregnancy weight is an important predictor of birth weight this a concern ${ }^{28}$; however, wasting was less common in older than in younger girls. Furthermore, the evidence that intakes of calcium, iron, vitamin A, riboflavin and vitamin $\mathrm{C}$ are inadequate in a substantial proportion of the group shows that the overall quality of the diet tends to be poor. This concern about dietary quality is reflected in the dietary patterns. Given the very important role played by green leafy vegetables in the diet, and the emphasis placed in recent years on the need to increase intakes, the fact that $20 \%$ of this group of young girls give a history of never consuming them is a cause for some concern.

We sought to explore whether social factors played any role in the dietary patterns and nutrient intakes of the girls. Girls from relatively poorer social circumstances could be characterized as coming from families with lower income and lower expenditure on food and parents who had achieved lower standards of formal education. In general, those girls with poorer social 
circumstances were relatively shorter, more likely to be underweight and to have diets of poorer quality. These girls had diets in which variety was less, and they were less likely to consume eggs, milk, meat and fruits compared with girls from families in better economic circumstances with parents of higher educational standard. When the intake of nutrients was assessed, the less affluent girls with relatively less well educated parents had significantly lower intakes of proteins, fat and riboflavin. It is interesting to note that these differences were more strongly related to differences in maternal education than in the educational level of the father. The socioeconomic status of a group or population is a multidimensional concept, which can be assessed as a function of a number of variables such as social position, educational level and income. Even though as a group these girls represent the most advantaged in Bangladesh society, it is important to note that the education of the parents had a clear relationship to nutritional status and patterns of food intake, as well as economic status playing an important role. We have previously noted the important relationship between family income and either growth or biochemical indices of nutritional status in school-age children from a similar background ${ }^{29,30}$.

The present study has generated information which has value as a reference and can be used as a basis from which policy can be developed. The indications are that the nutritional status of this group of adolescents should not be overlooked and suitable approaches designed to improve their nutrition should be considered. Whether, the approach is through education, or more direct interventions such as a school lunch programme, there is a clear need to change dietary patterns with a view to improving the nutritional status of the segment of population who will become mothers in the near future. The need to develop healthy food habits should be emphasized by appropriate nutrition education within the school curricula and its practice reinforced by appropriate behaviour in the schools.

\section{Acknowledgments}

The authors are indebted to the University of Dhaka, Bangladesh, Institute of Human Nutrition, University of Southampton, UK and the Geoffrey Taylor Memorial Fund, University of Southampton, UK for financial support for the study. The authors also express their sincere thanks to the participants of this study.

\section{References}

1 Jackson AA. Perinatal nutrition: the impact on postnatal growth and development. In: Gluckman PD, Heymann A, eds. Pediatrics and Perinatology. London: Arnold, 1996: 298-303.

2 Rees JM, Christine MT. Nutritional influences on physical growth and behavior in adolescence. In: Adams $G$, ed. Biology of Adolescent Bebaviour and Development. California: Sage Publications, 1989.

3 Eveleth PB, Tanner JM. Worldwide Variation in Human Growth, 2nd edn. Cambridge: Cambridge University Press, 1990.

4 Dreizen S, Spirakis CN, Stone RE. A comparison of skeletal growth and maturation in undernourished and well nourished girls before and after menarche. $J$. Pediatr. 1967; 70: 256-63.

5 Mitchell HS. Protein limitations and human growth. Am.J. Diet. Assoc. 1964; 44: 165-72.

6 Harrison KA, Fleming AF, Brigge ND, Rossifer CE. Growth during pregnancy in Nigerian primigravidae. Br.J. Obstet. Gynaecol. 1985; 5: 32-9.

7 Brabin L, Brabin BJ. The cost of successful adolescent growth and development in girls in relation to iron and vitamin A status. Am. J. Clin. Nutr. 1992; 55: 955-8.

8 Herbeth B, Spyckerella Y, Deschamps JP. Determinants of plasma retinol, beta-carotene and tocopherol during adolescence. Am. J. Clin. Nutr. 1991; 54: 884-9.

9 Matkovic V, llich Z. Calcium requirements for growth: are current recommendations adequate? Nutr. Rev. 1993; 51 : 171-80.

10 INFS. National Nutrition Survey of Rural Bangladesh, 8182. Institute of Nutrition and Food Sciences, Dhaka, Bangladesh: University of Dhaka, 1983.

$11 \mathrm{FAO} / \mathrm{WHO} / \mathrm{UNU}$. Energy and Protein Requirements. WHO Technical Report Series, no. 724. Geneva: WHO, 1985.

12 Ahmed F, Khan MR, Karim R, et al. Serum retinol and biochemical measures of iron status in adolescent school girls in urban Bangladesh. Eur. J. Clin. Nutr. 1996; 50: 34651.

13 NCHS. Growth Curves for Children O-18 Years. National Centre for Health Statistics, Washington, DC, 1976.

14 WHO. Physical Status: the Use and Interpretation of Antbropometry. WHO Technical Report Series, no. 854. Geneva: WHO, 1995.

15 Ali SMK, Pramanik MMA. Conversion Factors and Dietary Calculations. Institute of Nutrition and Food Sciences, Dhaka, Bangladesh: University of Dhaka, 1991.

16 INFS. Desbia Kbadyadrabyer Pusbtiman (Nutritive Value of Indigenous Foodstuffs). Dhaka, Bangladesh: University of Dhaka, 1992.

17 Gopalan C, Rama Sastri BV, Balasubramanian SC. Nutritive Value of Indian Foods. National Institute of Nutrition, Hyderabad, India: Indian Council of Medical Research, 1993.

18 Statistical Package for Sacial Sciences. SPSS/PC + version 4.0. Chicago, IL: SPSS Inc., 1990.

19 Islam N, Huq ATMZ, Rahman QM. Study of Urban Poverty in Bangladesh. Policy Papers, Final Report, vol. 2; Planning Commission, Government of Bangladesh and Asian Development Bank.

20 Spurr GB. Effects of chronic energy deficiency on stature, work capacity and productivity. In: Schurch B, Scrimshaw NS, eds. Chronic Enengy Deficiency, Consequences and Related Issues. $1 / \mathrm{D} / \mathrm{E} / \mathrm{C} / \mathrm{G}$, Lausanne, Switzerland, 1987: 95-134.

21 Garrow JS, James WPT. Human Nutrition and Dietetics. Edinburgh: Churchill Livingstone, 1993: 401

22 Pushpamma P, Geervani P, Lakshmi DN. Food intake, nutrient adequacy and anthropometry of adolescents in Andra Pradesh. Indian J. Nutr. Med. Res. 1982; 75: 61-7.

23 Durnin JVGA, Lonergem ME, Good J. A cross-sectional nutritional and anthropometric study, with an interval of 7 years, on 611 young adolescent school children. Br. J. Nutr. 1974; 32: 169-79. 
24 Whitehead RG, Paul AA, Cole TJ. Trends in food energy intakes throughout childhood from 1 to 18 years. Hum. Nutr. Appl. Nutr. 1982; 36: 57-62.

25 Canada National Survey. Nutrition: a National Priority. Ottawa, Canada, Department of National Health and Welfare, 1973.

26 Leibel LR. Behavioral and biochemical correlates of iron deficiency: a review. J. Am. Diet. Assoc. 1977; 71: 399-404.

27 Waterlow JC, Schurch B. Causes and mechanisms of linear growth retardation. Proceedings of and IDECG workshop. Euro. J. Clin. Nutr. 1994; 48: suppl 1.

28 Kramer MS. Determinants of low birth weight: methodological assessment and meta-analysis. Bulletin WHO 1987; 65: 663-737.

29 Ahmed F, Bhuyan MAH, Shaheen N, Barua S, Margetts BM,
Jackson AA. Effect of socio-economic conditions on growth of urban school age children of Bangladesh. Eur. J. Clin. Nutr. 1991; 45: 327-30.

30 Ahmed F, Mohiduzzaman M, Barua S, Shaheen N, Margetts BM, Jackson AA. Effect of family size and income on the biochemical indices of urban school children of Bangladesh. Eur. J. Clin. Nutr. 1992; 46: 465-73.

31 ICMR. Recommended Dietary Intakes for Indians. New Delhi: Indian Council of Medical Research, 1988.

32 World Health Organization. Diet, Nutrition and the Prevention of Chronic Diseases. Technical Report Series 767. Geneva: WHO, 1990.

33 World Health Organization. Trace Elements in Human Nutrition. Geneva: WHO, 1990. 